\title{
Działalność publiczna Tadeusza Staniewskiego w Swarzędzu w latach 1918-1939
}

W podpoznańskim mieście Swarzędz po raz pierwszy Polak objął stanowisko burmistrza w 1919 r. Był nim miejscowy kupiec i działacz społeczny Tadeusz Staniewski. W następnych latach aktywnie działał jako członek magistratu i przewodniczący Rady Miasta. Ponownie został wybrany burmistrzem w 1929 r. i pełnił tę funkcję nieprzerwanie do 1939 r., do wkroczenia wojsk niemieckich do Swarzędza. Aresztowany w pierwszych dniach września 1939 r., trafił do Fortu VII w Poznaniu, a później do obozu koncentracyjnego w Buchenwaldzie, gdzie zmarł 25 sierpnia $1940 \mathrm{r}$.

Rozproszone informacje dotyczące Tadeusza Staniewskiego można znaleźć w dwóch monografiach zajmujących się historią Swarzędza ${ }^{1}$. Stał się on też bohaterem kilku artykułów ${ }^{2}$ oraz okolicznościowej broszury, wydanej z okazji nadania jego imienia II Liceum Ogólnokształcącemu w Swarzędzu³. Jego biogram znalazł się w dwóch publikacjach poświęconych powstaniu wielkopolskiemu ${ }^{4}$. Niniejsza praca ma być próbą poszerzenia wiadomości na jego temat na podstawie kwerendy źródłowej w zbiorach Archiwum Państwowego w Poznaniu oraz w czasopismach wielkopolskich. Zauważyć

${ }^{1}$ W. Białek, Swarzędz 1638-1988, Swarzędz 1988; Dzieje Swarzędza: monografia (1638-1988), pod red. S. Nawrockiego, Poznań 1988.

2 A.M. Szafran, Tadeusz Staniewski (1873-1940), delegat Swarzędza na Polski Sejm Dzielnicowy, „Przegląd Wielkopolski” 2007, nr 2, s. 33-36; M. Szałek, Tadeusz Staniewski: pierwszy burmistrz Swarzędza w odrodzonej Polsce, „Prosto z Ratusza” 2007, nr 10, s. 10-11.

${ }^{3}$ Tadeusz Staniewski 1873-1940, pod red. I. Sobczyk, Swarzędz 2010.

${ }^{4}$ F. Fiedler, Powstanie Wielkopolskie: mieszkańcy Swarzędza w zwycięskim zrywie niepodległościowym 1918-1919, Swarzędz 2007, s. 44-45; Udziat mieszkańców Swarzędza i okolic w Powstaniu Wielkopolskim 1918-1919, Poznań 2015, pod red. A. Bartoszek, A. Małyszka, M. Pokorski, s. 7879 . 
tutaj warto, że zasoby Archiwum Państwowego dotyczące historii Swarzędza $\mathrm{w}$ okresie międzywojennym są nierówne, znacznie bogatsze $\mathrm{w}$ odniesieniu do lat dwudziestych niż trzydziestych. Prasa codzienna pozostaje źródłem wiedzy o wielu wydarzeniach istotnych dla miasta, takich jak Targi Meblowe w latach $1934-1938^{5}$ czy strajki stolarzy w latach 1937-1938 .

Tadeusz Staniewski urodził się 25 października 1873 r. w Kiełczewie, małej miejscowości pod Kościanem. Ojciec Stanisław (1845-1875?) był z zawodu nauczycielem, matka Stanisława (1851-1938) pochodziła z rodziny Juraszów i była siostrą Antoniego Stanisława Jurasza (1847-1923), wybitnego laryngologa polskiego. Ojciec bardzo wcześnie osierocił rodzinę, a matka przeniosła się z dziećmi do Poznania, gdzie prowadziła sklep z towarami kolonialnymi. Tadeusz Staniewski ukończył Gimnazjum Fryderyka Wilhelma w Poznaniu. W latach 1896-1898 odbył praktykę w aptece Zygmunta Grochowskiego w Miłosławiu, zyskując uprawnienia drogerzysty ${ }^{7}$. Po zawarciu w $1898 \mathrm{r}$. związku małżeńskiego osiadł w Swarzędzu, gdzie otworzył drogerię. Sklep ten, mieszczący się w kamienicy pod adresem Rynek 12, szybko uczynił go osobą powszechnie znaną $\mathrm{w}$ mieście. Próbował także swoich sił $\mathrm{w}$ innych dziedzinach, m.in. zajmował się produkcją papierosów, a w latach 30 . był właścicielem autobusu dowożącego mieszkańców Swarzędza do Poznania. Pierwsze kroki w działalności publicznej stawiał już w pierwszych latach XX w. W 1906 r. Tadeusz Staniewski został wiceprezesem Rady Nadzorczej tzw. Banku Ludowego, spółki kredytowo-oszczędnościowej powołanej przez miejscowego proboszcza. W 1909 r. kandydował do Rady Miejskiej, w latach 1911-1914 był członkiem tzw. nadzoru kościelnego swarzędzkiej parafii. Był to urząd honorowy, obieralny, pełnienie tej funkcji potwierdza wysoką rangę osoby w lokalnej społeczności. Tadeusz Staniewski zyskał uznanie swarzędzan zarówno jako działacz charytatywny, jak i jako obrońca sprawy narodowej.

${ }^{5}$ Drugie Targi meblowe w Swarzędzu, "Nowy Kurier” 1935, nr 161, s. 6; Przed zamknięciem Targów Meblowych, "Orędownik” 1938, nr 218, s. 5; (sd), Swarzędz. Izba rzemieślnicza wystawcom meblowym, „Kurier Poznański” 1935, nr 7, s. 9; Swarzędz pod znakiem IV Targów Meblowych, „Orędownik" 1938, nr 202, s. 4; Szyna, Wszystkie piłki, dtuta, heble Robia meble, meble, meble... Miasto stolarzy - Targi Meblowe w Swarzędzu, "Ilustracja Polska” 1934, nr 41, s. 7, 15; W przededniu IV. Targów Meblowych w Swarzędzu, „Nowy Kurier” 1938, nr 191, s. 9; W sprawie Targów Meblowych w Swarzędzu, "Orędownik” 1938, nr 263, s. 6; Wielkie zebranie stolarzy w Swarzędzu domaga się zawieszenia zarządu Targów Meblowych, „Kurier Poznański” 1938, nr 498 [wyd. wieczorne], s. 18.

${ }^{6}$ Czeladź stolarska postanowiła walczyć aż do zwycięstwa, "Nowy Kurier" 1938, nr 203, s. 7; O umowę zbiorową w przemyśle stolarskim w Swarzędzu, „Nowy Kurier” 1938, nr 143, s. 7; Strajk stolarzy w Swarzędzu, "Orędownik” 1937, nr 93, s. 3; nr 94, s. 6, nr 95, s. 6.

${ }^{7}$ Drogerzysta (inaczej drogista) - handlujący materiałami aptecznymi, za: Stownik języka polskiego, pod red. J. Karłowicza, t. 1, Warszawa 1900, s. 560. 


\section{W latach 20.}

Już w okresie poprzedzającym wybuch I wojny światowej narastają w Swarzędzu konflikty społeczne, wyrażające się głównie w rywalizacji pomiędzy Towarzystwem Przemysłowców a Towarzystwem Robotników. Spory pomiędzy nimi położyły się cieniem na wynikach wyborów do Rady Miejskiej w 1909 r., kiedy sukces odnieśli tylko niemieccy kandydaci. Zrodziła się wówczas idea zbudowania Domu Katolickiego, który jako miejsce spotkań dla wszystkich polskich organizacji i stowarzyszeń miał wzmocnić pozycję rodzimych działaczy. Społeczeństwo swarzędzkie żywiło to pragnienie przez wiele lat, podejmując kolejne próby zespolenia wysiłków różnych ugrupowań. Ostatecznie zjednoczony Komitet Budowy powstał w 1914 r., ale jego działalności położył kres wybuch wojny. We wszystkich tych inicjatywach ważną rolę odgrywał Tadeusz Staniewski. Był on postrzegany jako człowiek kompromisu, obdarzony zdolnością łagodzenia sporów ${ }^{8}$.

Kiedy w listopadzie 1918 r., w obliczu końca wojny, w Wielkopolsce zaczęto tworzyć rady robotnicze i żołnierskie, to rewolucyjne wrzenie nie ominęło Swarzędza. Miarą zaufania, jakim mieszkańcy miasta darzyli Tadeusza Staniewskiego, jest fakt, że został on wybrany do zarządu swarzędzkiej Rady. Jak podaje czasopismo „Postęp" pada 1918] Radę żołnierzy i robotników. W ostatniej zasiada 8 Polaków, 3 Niemców i 1 żyd; w radzie żołnierzy 4 Polaków i 4 Niemców. Ściślejszy zarząd tworzą: ks. Janicki, Staniewski i Ignacy Mikołajewski. Wszystko w spokoju i porządku"10. Z ramienia swarzędzkiej Rady Robotniczej i Żołnierskiej Tadeusz Staniewski w listopadzie 1918 r. został wybrany delegatem do Sejmu Dzielnicowego ${ }^{11}$. Według anonimowej relacji pt. Pierwsze dni powstania $1918 \mathrm{r}$. apteka Tadeusza Staniewskiego stała się miejscem, gdzie w tajemnicy przed władzami niemieckimi swarzędzanie spotykali się, przygotowując wybuch powstania. „29 XII 1918 przybył p. Staniewski w towarzystwie dwóch zbrojnych powstańców polskich do ówczesnego burmistrza p. Glabisza [Brunona Glabischa] na ratusz i oznajmił, że podlega władzy polskiej, ponieważ rada robotniczo-żołnierska została zniesiona. Krótko potem nadesłano p. Staniewskiemu znamienny dokument, list z tut. żandarmerji pruskiej, zatytułowany do prezydenta republiki swarzędzkiej, donosząc o poddaniu się władzy polskiej"12.

${ }^{8}$ B. Ksit, Działalność publiczna Tadeusza Staniewskiego w Swarzędzu do roku 1918, „Przegląd Archiwalno-Historyczny" 2018, t. 5, s. 43-61.

9 [Utworzenie Rady Żołnierzy i Robotników w Swarzędzu], „Postęp” 1918, nr 267, s. 3.

${ }^{10} \mathrm{~W}$ cytatach zachowano pisownię oryginalną.

11 A.M. Szafran, Tadeusz Staniewski...

12 Pierwsze dni powstania 1918 r., "Głos Swarzędza” 1935, nr 1, s. 1-2. 
Tego samego dnia (29 grudnia) Tadeusz Staniewski objął funkcję komisarza obwodowego (po von Bodungenie) ${ }^{13}$. Podczas wielkiego wiecu nad swarzędzkim jeziorem proklamowano „Powstanie Polski”, stamtąd pochód przemaszerował na Rynek, pod mieszkanie Tadeusza Staniewskiego. On wyniósł ufundowaną przez siebie polską chorągiew, którą entuzjastycznie obniesiono wokół Rynku, a następnie zawieszono na ratuszu ${ }^{14}$.

Na miejsce Rady Robotników i Żołnierzy powołano Radę Ludową, której przewodniczącym był najpierw Tadeusz Staniewski, później ks. Tadeusz Mroczkowski. Zamieściła ona w "Orędowniku Powiatu Poznańskiego-Wschodniego" („Kreis-Blatt des Kreises Posen-Ost”) z 24 stycznia 1919 r. Obwieszczenie $e^{15}$ następującej treści: „Na podstawie obwieszczenia Komisarjatu Naczelnej Rady Ludowej z dnia 9 stycznia 1919 przejęliśmy władzę wykonawczą nad Swarzędzem miasto oraz obwodem Swarzędza i podajemy co następuje do wiadomości:

1. Celem podtrzymywania ogólnego porządku wzywamy wszystkich bez różnicy narodowości do bezwarunkowego podporządkowania się pod nasze rozkazy.

2. Wszelkie pisma oraz osobiste zapytania będą $w$ tym języku $z$ naszej strony załatwione, $\mathrm{w}$ jakim nam stawione zostały.

3. Do podejmowania rewizji domowych są tylko ci żołnierze uprawnieni, którzy biało-czerwoną przepaskę z pieczęcią Rady Ludowej mają i mogą się piśmienną, ostemplowaną legitymacją powyższej władzy wykazać.

4. Do noszenia broni są tylko te osoby upoważnione, które się w posiadaniu wykazu Rady Ludowej znajdują.

5. Polowania zbiorowe oraz polowania zwykłe są bez zezwolenia Rady Ludowej zakazane.

6. Zwraca się uwagę na to, że do każdej podróży do Poznania potrzebny jest wykaz, przy czem tylko te wykazy ważność mają, które od Rady Ludowej wystawione zostały".

Władysław Białek zwraca uwagę, że przejęcie władzy w Swarzędzu odbyło się bez incydentów. Brak oporu urzędników pruskich tłumaczy tym, że powyższe zarządzenia nie dyskryminowały ludności niemieckiej ${ }^{16}$. Tymczasem w Swarzędzu przystąpiono do odtwarzania administracji miejskiej. Tymczasowy stan utrzymał się do wiosny. W kwietniu 1919 r. odbyły się wybory do Rady Miejskiej, na podstawie "Regulaminu dotyczącego wyborów do Rad Miejskich", ogłoszonego przez Naczelną Radę Ludową w Poznaniu.

${ }^{13}$ W książce Dzieje Swarzędza: monografia... można znaleźć dwie daty objęcia tej funkcji przez Staniewskiego. S. Nawrocki podaje - 29 grudnia, s. 109; Z. Kaczmarek - luty 1919 r., s. 113.

14 Pierwsze dni powstania 1918 r....

${ }^{15}$ Obwieszczenie Rady Ludowej w Swarzędzu, „Orędownik Powiatu Poznańskiego-Wschodniego" 1919, nr 7, s. 8.

${ }^{16}$ W. Białek, Swarzędz 1638-1988 ..., s. 64. 
Nowo wybrana Rada Miejska zdecydowała, że burmistrzem będzie nadal Brunon Glabisch, a Tadeusz Staniewski pozostanie upoważnionym przez radę członkiem Magistratu ${ }^{17}$.

Radość z odzyskanej niepodległości nie może przesłonić faktu, że był to dla Swarzędza - podobnie jak dla całej Wielkopolski - bardzo trudny czas. Konieczność zaopatrywania walczących wojsk, ciężka zima 1918/1919 sprawiły, że w mieście brakowało węgla, a nawet podstawowych produktów spożywczych. Wielkie wyzwanie stanowiły migracje - Niemcy wyjeżdżali do Niemiec, Polacy wracali z emigracji, jeńcy wojenni z Rosji. W 1919 r. miasto liczyło 3350 mieszkańców, w tym ok. 1700 Polaków. Drugą połowę stanowili Niemcy (34 proc.) i Żydzi (16 proc.). Według spisu powszechnego, w 1921 r. liczba mieszkańców nie zmieniła się, natomiast proporcje tak. Na 3358 mieszkańców 2753 to Polacy ${ }^{18}$. Pewien obraz tamtych czasów daje skarga, którą Tadeusz Staniewski skierował 11 marca 1922 r. „Do Województwa Poznańskiego w Poznaniu". Jako właściciel fabryki tabaki został zaskoczony niezwykle wysoką podwyżką ceny gazu. Surowiec pochodził z gazowni miejskiej, a magistrat uzasadnił podwyżkę rosnącą ceną węgla, który gazownia musi zakupić. Nie wiedząc o podwyżce, zainteresowany wniósł opłatę po zwyczajowej cenie, co doprowadziło do wizyty komornika. Wtedy zapłacił żądaną kwotę, „,nie chcąc być na wstyd narażony, po 25 latach pracy obywatelskiej w tutejszym mieście przez polskie władze niesłusznie być fantowany ${ }^{19}$. Wobec tego zakładam uroczysty protest, ponieważ $\mathrm{w}$ tym przypadku nadużył Magistrat swej władzy, każąc bezwzględnie fantować niesłusznie. [...] Mam nadzieję, że Prześwietne Województwo takiego bezprawia tolerować nie będzie i odpowiednie czynniki pociągnie do odpowiedzialności" ${ }^{20}$.

Chociaż mieszkańcy Swarzędza energicznie podjęli wysiłek budowania odrodzonego państwa polskiego, niemniej w kolejnych latach funkcjonowanie samorządu miejskiego napotykało wiele przeszkód. Jak piszą badacze zajmujący się dziejami Swarzędza ${ }^{21}$, w historii miasta w okresie dwudziestolecia międzywojennego zwraca uwagę fakt, że w pierwszych latach niepodległości zachodziły tutaj częste zmiany na stanowisku burmistrza. Niemiec Brunon Glabisch był nim do 1 października 1919 r. Potwierdza to pismo zatytułowane „Do Rejencji w Poznaniu przez starostwo Poznań-Wschód. Swarzędz 30.9.1919”. Czytamy w nim: „Uchwałami Rady miasta z dnia 2.9.1919 i magi-

${ }^{17}$ APP, Zespół: 53/4389 Akta miasta Swarzędz, Jednostka: 296, k. 5.

${ }^{18}$ W. Białek, Swarzędz 1638-1988..., s. 87.

${ }^{19}$ Fantować - robić zajęcie cudzych rzeczy na mocy wyroku, za: Stownik języka polskiego, pod red. J. Karłowicza, t. 1, Warszawa 1900, s. 720.

${ }^{20}$ APP, Zespół: 296 Urząd Wojewódzki Poznański, Jednostka 1481: Administracja miasta Swarzędza, k. 23-24.

${ }^{21}$ W. Białek, Swarzędz 1638-1988 ...; Z. Kaczmarek, W Polsce odrodzonej, [w:] Dzieje Swarzędza: monografia... 
stratu 29.9.19 został - przez dawniejszą radę miejską wybrany - burmistrz tutejszego miasta pan Glabisch z dniem 1 października br. ze swych obowiązków zwolniony, stosownie do rozporządzenia Komisarjatu Naczelnej Rady Ludowej z 9 maja 1919 z powodu nieznajomości języka polskiego. Aż do nowego wyboru przejął wszelkie czynności urzędowe zatwierdzony przez Rejencję zastępca burmistrza pan Staniewski"22.

Tadeusz Staniewski przez dziewięć miesięcy pełnił tę funkcję społecznie. 26 lipca 1921 r. magistrat poprosił wojewodę poznańskiego o przysłanie burmistrza komisarycznego. W piśmie magistrat wyjaśniał, że żaden z jego członków nie czuje się na siłach objąć stanowiska ze względu na inne obowiązki. W odniesieniu do Tadeusza Staniewskiego padły słowa: „Pan Staniewski już przeszło trzy lata jest członkiem magistratu i przeszło 9 miesięcy zastępował burmistrza bezinteresownie, poniósłszy rzeczywiste straty $w$ interesie ${ }^{\prime 23}$. Nie udało się ustalić, jak długo Tadeusz Staniewski zasiadał w Magistracie, ale w świetle wyżej cytowanej jego skargi można przyjąć, że w marcu 1922 r. nie był już ławnikiem.

15 kwietnia 1924 r. Rada Miejska jednogłośnie wybrała burmistrzem Hieronima Dąbrowskiego. W 1925 r. wybrano nową Radę Miejską, w której Tadeusz Staniewski objął funkcję przewodniczącego. Rozpoczął się burzliwy okres w historii miasta ze względu na konflikt pomiędzy burmistrzem i magistratem - z jednej strony, a Radą Miejską - z drugiej.

Zarówno przewodniczący Tadeusz Staniewski, jak i jego zastępca Wawrzyn Lisiecki, reprezentowali w Radzie Miejskiej Narodową Partię Robotniczą. Popularność tej partii w Swarzędzu nie dziwi, gdyż w całej Wielkopolsce cieszyła się ona największym powodzeniem w małych miastach. Partia ta powstała 23 maja 1920 r., po zjednoczeniu się Narodowego Stronnictwa Robotników i Narodowego Związku Robotników. Program tej partii łączył troskę o ludzi żyjących z pracy swoich rąk - nie tylko robotników fabrycznych, bo tych było niewielu w miastach pozbawionych ciężkiego przemysłu - z przywiązaniem do wartości narodowych. Wciąż idea solidarności narodowej była jej bliższa niż hasło walki klas. Głosiła potrzebę przemian społecznych i politycznych, ale drogą ewolucyjną i z poszanowaniem prawa własności. „Obóz narodowo-robotniczy miał więc spełniać w konkretnej ówczesnej rzeczywistości społecznej rolę pośrednika między opartym na materialistycznych podstawach klasowym ruchem robotniczo-zawodowym a opartym na papieskiej encyklice idealistycznym ruchem chadeckim. Dlatego też w praktycznej działalności NPR swym pośrednim stanowiskiem pragnęła pozyskać dla swej ideologii jak najszersze rzesze członkowskie, by

${ }^{22}$ APP, Zespół: 53/4389 Akta miasta Swarzędza, Jednostka: 57, k. 200.

${ }^{23}$ Tamże, k. 239. 
w ten sposób osłabić nie tylko klasowy ruch robotniczy, ale także rozwijającą się na terenie Wielkopolski chadecję"24.

Drugą pod względem popularności partią w Swarzędzu był Związek Ludowo-Narodowy (od 1928 r. - Stronnictwo Narodowe). Członkowie tej partii działali we wpływowych, cieszących się długą tradycją organizacjach, takich jak "Sokół”, Towarzystwo Przemysłowców oraz w kołach katolickich i śpiewaczych. „Endecja prezentowała program, który na czoło wysuwał zasady solidaryzmu i nacjonalizmu, zachowania nienaruszalności własności prywatnej i uprzywilejowanej roli Kościoła katolickiego. W programie wskazywano na Niemcy, jako głównego wroga państwa polskiego. Program ten odpowiadał poważnej części społeczeństwa swarzędzkiego, stąd też około 50 proc. często głosowało na endecję" 25 .

Zwraca uwagę fakt, że sympatie polityczne były w znacznym stopniu niezależne od pochodzenia społecznego mieszkańca Swarzędza. W Aktach miasta Swarzędza zachowało się zestawienie radnych miasta, wybranych w latach 1921 i 1925. W 1921 r. czterech radnych zostało wybranych z Listy Obywatelskiej (endecja), dwóch z Listy Inwalidów, dwóch z NPR, dwóch z listy niemieckiej. Wśród nich znaleźli się: jeden fabrykant, trzech kupców, malarz, piekarz, palacz, restaurator, dwóch stolarzy. Wszyscy mieli wykształcenie elementarne. Natomiast w 1925 r. było czterech radnych z Listy Obywatelskiej, pięciu z NPR, jeden z listy niemieckiej, w tym: jeden fabrykant, trzech kupców, handlarz, dwóch stolarzy, mistrz piekarski, kolejarz, robotnik. Dziewięciu z nich miało wykształcenie elementarne, jedna osoba (czyli Tadeusz Staniewski) - średnie ${ }^{26}$.

Małe miasteczko Swarzędz odtworzyło w mikroskali podziały polityczne charakterystyczne dla całej Wielkopolski. Niemniej badacze podkreślają, że w konflikcie pomiędzy burmistrzem Swarzędza a Radą Miejską ważną rolę odegrały osobowości głównych adwersarzy - autokratyczny sposób bycia burmistrza Dąbrowskiego i niespokojne, konfliktowe usposobienia radnego Wawrzyna Lisieckiego ${ }^{27}$. W latach 1926-1927 Tadeusz Staniewski musiał ponownie wykazać się umiejętnością wygaszania konfliktów. Jako przewodniczący Rady Miejskiej dążył do tego, by osobiste spory urzędników nie

${ }^{24}$ Cz. Demel, J. Krawulski, K. Rzepa, Działalność NSR i NPR w Wielkopolsce w latach 19171937, Warszawa-Poznań 1980, s. 102-103.

${ }^{25}$ Z. Kaczmarek, W Polsce odrodzonej..., s. 186-187.

${ }^{26}$ APP, Zespół 53/4389: Akta miasta Swarzędza, Jednostka 294: Wybory do Rady Miejskiej, k. 78 .

${ }^{27}$ W. Białek, Swarzędz 1638-1988 ..., s. 96-97; Z. Kaczmarek, W Polsce odrodzonej..., s. 128. Informacje na temat przebiegu tego konfliktu można znaleźć w zbiorach Archiwum Państwowego w Poznaniu, w zespole 4389 Akta miasta Swarzędza (jednostki 294-295: Wybory do Rady Miejskiej, jednostka 302: Posiedzenie Rady Miejskiej), oraz w zespole 296 Urząd Wojewódzki Poznański (jednostka 1481: Administracja miasta Swarzędza). 
wpływały na funkcjonowanie całego miasta, co nie zawsze spotykało się ze zrozumieniem jego oponentów.

Według Zygmunta Kaczmarka, konflikt rozpoczął się w lutym 1926 r., kiedy Rada Miejska uchwaliła wotum nieufności wobec burmistrza i nie zatwierdziła decyzji magistratu w sprawie przeznaczenia czterech tysięcy złotych na roboty publiczne $\mathrm{w}$ celu zatrudnienia bezrobotnych ${ }^{28}$. W tych trudnych latach opóźnienia $\mathrm{w}$ pomocy dla bezrobotnych musiały wywołać zrozumiały niepokój. W burzliwych tygodniach po zamachu majowym Józefa Piłsudskiego burmistrz zwrócił się o poparcie do Polskiej Partii Socjalistycznej (powstała w Swarzędzu 6 czerwca 1926 r.). Zwołano wielki wiec, na którym potępiono Radę za brak troski o bezrobotnych. Kolejne posiedzenia obu władz miejskich prowadziły właściwie tylko do wzajemnego blokowania postanowień. 28 sierpnia $1926 \mathrm{r}$. Tadeusz Staniewski zawiadomił Magistrat, że następne "posiedzenie Rady Miejskiej odbędzie się w poniedziałek dnia $30 \mathrm{bm}$ o godz 3-ciej po południu na Sali ratuszowej. Ze względu na podburzający charakter wieca odbytego dnia $26 \mathrm{bm}$ wykluczam publiczność" ${ }^{29}$. Po tym posiedzeniu, w piśmie do Urzędu Wojewódzkiego z 6 września 1926 r., Magistrat skarżył się na działanie Rady Miejskiej. Ostatecznie „Magistrat doszedł do przekonania, że dalsza praca z obecną Radą Miejską jest nie możliwa i stawił wniosek o jej rozwiązanie" ${ }^{\prime 30}$. Wojewoda Poznański zareagował na tę skargę i upomniał Tadeusza Staniewskiego pismem z 14 września 1926 r., zatytułowanym Do własnych rąk Przewodniczacego Rady Miejskiej Staniewskiego. Czytamy w nim: „Stwierdzono tu, że Pan wbrew przepisowi 839 ord[ynacji] m[iejskiej] nie zwołuje posiedzenia Rady Miejskiej na żądanie Magistratu - w razie zaś zwołania posiedzenia nie umieszcza Pan na porządku obrad spraw przez Magistrat wskazanych, przez co utrudnia Pan prawidłową administrację i naraża miasto na straty" ${ }^{\prime 3}$. Rada Miejska postanowiła sięgnąć po pomoc prasy. W „Dzienniku Poznańskim” ukazał się artykuł, zarzucający burmistrzowi Dąbrowskiemu, że "sabotuje uchwały Rady Miejskiej bez żadnej uzasadnionej potrzeby"32. W odpowiedzi Hieronim Dąbrowski wystosował pismo do redaktora odpowiedzialnego „Dziennika Poznańskiego" Stanisława Nagórskiego. Dąbrowski stanowczo odrzuca w nim wszystkie zarzuty jako kłamliwe. Ocenia, że te "stałe nieporozumienia pomiędzy Magistratem a Radą Miejską" są "powodowane złą wolą ze strony prze-

${ }^{28}$ Z. Kaczmarek, W Polsce odrodzonej..., s. 128.

${ }^{29}$ APP, Zespół 53/4389: Akta miasta Swarzędza, Jednostka: 302, k. 4.

${ }^{30}$ APP, Zespół 53/296: Urząd Wojewódzki Poznański, Jednostka 1481: Administracja miasta Swarzędza, k. 68.

${ }^{31}$ APP, Zespół 53/4389: Akta miasta Swarzędza, Jednostka: 302, k. 7.

32 P. Komisarz rządowy w roli kacyka. Głos obywateli m. Swarzędza, „Dziennik Poznański” 1926, nr 222, s. 6. 
wodniczącego Rady Miejskiej [Tadeusza Staniewskiego] i jego zastępcy"33. W tej sytuacji działalność władz miejskich została sparaliżowana. Spór śledzony był uważnie przez starostę powiatowego i wojewodę poznańskiego. Ponieważ nie zdołano go rozstrzygnąć na miejscu, dotarł w końcu do Rady Ministrów. 12 grudnia 1926 r., decyzją premiera Józefa Piłsudskiego, Rada Miejska w Swarzędzu została rozwiązana ${ }^{34}$.

Kolejna Rada Miejska na początku 1928 r. dokonała wyboru nowych członków magistratu (Tadeusz Staniewski został wybrany ławnikiem) i rozpisała konkurs na urząd burmistrza ${ }^{35}$. Po dwóch nieudanych konkursach i burzliwych dyskusjach postanowiono wybrać na urząd burmistrza członka magistratu Tadeusza Staniewskiego. Ten wybór okazał się trafny. Wieloletnie doświadczenie w pracy samorządowej, znajomość lokalnego środowiska sprawiły, że Tadeusz Staniewski był w stanie sprawnie zarządzać miastem.

\section{Tadeusz Staniewski jako burmistrz miasta Swarzędza (1929-1939)}

W latach dwudziestolecia międzywojennego Swarzędz dzielił wszystkie trudności, z jakimi zmagało się państwo polskie. Autor artykułu w „Nowym Kurierze" z 1931 r. pt. Swarzędz - miasto stolarzy. Drogi rozwoju, potrzeby i bolaczki pracowitego sąsiada stolicy Wielkopolski ${ }^{36}$ podkreślił, jakie znaczenie dla miasta miało położenie w bliskości Poznania: „Jest to typowe miasteczko ‘podmiejskie», oddychające atmosferą wielkiego sąsiada, uzależnione gospodarczo i kulturalnie od swego centrum. Ani piękne położenie miasta, ani wysiłki miejscowego samorządu, nie mogą go wyrwać z zastoju. [...] Czysty, schludny, gęsto zabudowany Swarzędz liczy obecnie 4200 mieszkańców o ludności przeważnie robotniczej i rzemieślniczej, wśród której przeważają stolarze".

Najpoważniejsze problemy, z jakimi musiał zmierzyć się Tadeusz Staniewski, obejmując stanowisko burmistrza, to zaostrzająca się sytuacja polityczna oraz kryzys gospodarczy i związane z nim bezrobocie. Wydaje się, że dołożył wszystkich starań, by przeprowadzić miasto przez te burzliwe lata w najlepszy możliwy sposób w danych warunkach.

33 APP, Zespół 53/296: Urząd Wojewódzki Poznański, Jednostka 1481: Administracja miasta Swarzędza, k. 83-86.

34 Z. Kaczmarek, W Polsce odrodzonej..., s. 130.

35 APP, Zespół 53/4389: Akta miasta Swarzędza, Jednostka 294: Wybory do Rady Miejskiej, k. 183.

${ }^{36}$ Swarzędz - miasto stolarzy. Drogi rozwoju, potrzeby i bolaczki pracowitego sasiada stolicy Wielkopolski, „Nowy Kurier” 1931, nr 267, s. 10. 
Kiedy po zamachu majowym doszło do rozłamu w szeregach Narodowej Partii Robotniczej, Tadeusz Staniewski przyłączył się do secesyjnej grupy NPR-Lewica, popierającej Józefa Piłsudskiego. Następnie stał się członkiem Bezpartyjnego Bloku Współpracy z Rządem³ ${ }^{37}$ Później wspierał działalność Obozu Zjednoczenia Narodowego, co potwierdza następująca notatka w „Nowym Kurierze” z 1938 r.: „Pod przewodnictwem p. Walczaka odbyło się zebranie miejscowego Oddziału Obozu Zjednoczenia Narodowego przy udziale przeszło 150 osób. Referat wygłosił burmistrz Staniewski, charakteryzując sytuację międzynarodową, naszą sytuację wewnętrzną oraz omawiając sprawę wyborów. W dyskusji obecni wypowiedzieli się za solidarnym, gremialnym wzięciem udziału w wyborach do Izb Ustawodawczych. W nadchodzącą niedzielę o godz. 12 odbędzie się na Rynku w Swarzędzu staraniem Obozu Zjednoczenia Narodowego wielki wiec w sprawie Śląska Zaolziańskiego" ${ }^{38}$.

Jako urzędnik samorządowy pozostawał lojalny wobec władz sanacyjnych, być może podzielał ich opinię, że budowanie silnego, sprawnego państwa wymaga utożsamienia się pracowników państwowych wszelkiego szczebla z polityką rządu. Niemniej nie można go chyba nazwać "piłsudczykiem”, nie ma żadnego śladu na to, by osoba Marszałka odgrywała dla Tadeusza Staniewskiego rolę autorytetu, choć trudno to ocenić w sytuacji, gdy nie zachował się ani jeden tekst wystąpienia swarzędzkiego burmistrza. W początkach budowania niepodległego państwa polskiego Tadeusz Staniewski był nawet posądzony o poznański separatyzm. Anonimowy "Świadek" zamieścił w "Gońcu Wielkopolskim” z 6 maja 1922 r. opis swarzędzkich obchodów „rocznicy 3. Maja”. Po wielkim pochodzie od kościoła do ratusza członkowie towarzystw i dziatwa szkolna zebrali się wokół mównicy. „Pierwszy mówca $\mathrm{w}$ wojskowym mundurze $\mathrm{w}$ randze oficera krótkiem swem przemówieniem zainteresował słuchaczy. Drugi mówca p. Staniewski mówił dużo o przeszłości, tem mniej o teraźniejszości. Mówił bez zagrzania ducha, bez dodania najmniejszej otuchy na przyszłość. Ani jeden ani drugi mówca nie wzniósł okrzyku na cześć Rzeczypospolitej Polskiej, ani na cześć Naczelnika Państwa. Toteż ospale zakończyła się uroczystość obchodu pamiątkowej rocznicy 3. Maja w Swarzędzu. Pachnie to wszystko separatyzmem"39.

Inaczej było $\mathrm{w}$ roku 1931. W piśmie do Starosty Powiatowego Powiatu Poznańskiego z 12 listopada 1931 r. Tadeusz Staniewski donosił, że wyko-

${ }^{37}$ W odpowiedzi na wezwanie ze Starostwa Powiatowego z 8 stycznia 1932 r. Tadeusz Staniewski przesłał „imienny spis członków Magistratu i Rady Miejskiej”, w którym przy liście nazwisk znajdują się odręczne dopiski charakteryzujące przynależność partyjną. Przy jego nazwisku jako burmistrza widnieje skrót. BBWR; APP, Zespół 53/4389: Akta miasta Swarzędza, Jednostka 296: Wybory członków do Rady Miejskiej, k. 21.

38 "Nowy Kurier" 1938, nr 223, s. 9.

${ }^{39}$ Swarzędz [Obchody rocznicy 3 Maja], "Goniec Wielkopolski” 1922, nr 104, s. 2. 
nał rozporządzenie z 4 listopada 1931 r. i urządził uroczyste obchody trzynastej rocznicy Niepodległości 11 listopada. Po nabożeństwie i pochodzie na rynek „niżej podpisany burmistrz wzniósł trzykrotny okrzyk na cześć Rzeczypospolitej Polskiej, Pana Prezydenta, Wojska Polskiego i Marszałka J. Piłsudskiego" ${ }^{40}$.

W czasie kadencji Tadeusza Staniewskiego funkcjonowało w Swarzędzu ponad pięćdziesiąt ${ }^{41}$ organizacji społecznych i stowarzyszeń, z którymi władze miasta regularnie współpracowały. Staniewski szczególnie wspierał działalność Straży Pożarnej, od 1931 do 1934 r. był jej honorowym członkiem, później honorowym prezesem ${ }^{42}$. W przypadku Tadeusza Staniewskiego wspieranie działalności towarzystw było zapewne kontynuacją obywatelskiej postawy, jaką przejawiał od młodości. Zarazem wpisywało się w politykę ówczesnego rządu, który oczekiwał od urzędników zaangażowania we wszystkich dziedzinach życia społecznego i wychowywania obywateli swoim przykładem. Jak pisze Piotr Okulewicz: „Liderzy sanacyjni starali się przejąć kontrolę i podporządkować urzędom centralnym wszelkie organy samorządowe. [...] Podjęto również próbę przejęcia kontroli nad wszelkimi organizacjami społecznymi, związkami kombatantów, stowarzyszeniami charytatywnymi czy sportowymi, które mogły być pomocne w podniesieniu wartości bojowej obywateli i ułatwić mobilizację w przypadku wojny. Poprawieniu zdolności mobilizacyjnej społeczeństwa służyły wreszcie różne akcje propagandowe zmierzające do podniesienia prestiżu państwa. Defilady, szumnie obchodzone rocznice wydarzeń $z$ dalszej i bliskiej historii Polski, zloty i kongresy miały podnieść $\mathrm{w}$ społeczeństwie poczucie identyfikacji obywateli z odrodzonym państwem" 43 .

Zarówno Akta miasta Swarzędza, jak i artykuły w ówczesnej prasie potwierdzają, że i w małym Swarzędzu uroczyście obchodzono patriotyczne wydarzenia. Uczczono m.in. rocznice powstań: listopadowego ${ }^{44}$, styczniowego $^{45}$ i wielkopolskiego ${ }^{46}$, "Miesiąc Pomorza" 47 , uchwalenie nowej konstytu-

${ }^{40}$ APP, Zespół 53/4389: Akta miasta Swarzędza, Jednostka 350: Obchody świąt narodowych, k. 89.

${ }^{41}$ S. Dytkiewicz, Swarzędz miasto stolarzy, Swarzędz 1936, s. 19.

${ }^{42}$ W. Buczyński, Tadeusz Staniewski jako organizator i działacz społeczny, na przykładzie ochrony przeciwpożarowej Swarzędza, [w:] Tadeusz Staniewski 1873-1940..., s. 34-38.

${ }^{43}$ P. Okulewicz, Obóz sanacyjny w województwie poznańskim w latach 1926-1935, Poznań 2014, s. 67.

${ }^{44}$ APP, Zespół 53/4389: Akta miasta Swarzędza, Jednostka 350: Obchody świąt narodowych, k. 17, 19, 30.

45 Tamże, k. 140.

46 Tamże, k. 232.

47 Tamże, k. 80, 86. 
$\mathrm{cji}^{48}$, rocznicę odzyskania niepodległości ${ }^{49}$. Tadeusz Staniewski przemawiał podczas jubileuszu Koła Śpiewackiego ${ }^{50}$, na zlocie Młodych Polek ${ }^{51}$, z okazji otwarcia publicznej czytelni prasy ${ }^{52}$. Był przewodniczącym Komitetu Obchodu Cudu nad Wisłą ${ }^{53}$, Komitetu Obchodu Zwycięstwa pod Wiedniem ${ }^{54}$. „Nowe władze państwowe skupiły swoją uwagę również na upowszechnianiu wiedzy i umiejętności z zakresu przysposobienia wojskowego społeczeństwa" ${ }^{\prime \prime 5}$. Rola szczególnego autorytetu moralnego przypadła weteranom walk niepodległościowych. Kiedy w 1934 r. ukazał się pierwszy numer czasopisma „Zew Polski Zachodniej”, w podtytule określonego jako „organ poświęcony idei kombatanckiej", w słowie wstępnym Do czytelników! napisano: „[...] ruch kombatancki zachodniej Polski jedynie drzemał, aby w ostatnim czasie obudzić się do silnej akcji i obecnie jesteśmy świadkami coraz potężniej rosnącej fali ruchu niepodległościowo-kombatanckiego, a idea kombatancka, idea służenia ofiarnie Państwu i tylko Państwu, wnika w coraz szersze komórki naszego życia zbiorowego"56. Także Tadeusz Staniewski w 1934 r. został członkiem Związku Weteranów Powstań Narodowych Rzeczypospolitej Polskiej - koło Swarzędz ${ }^{57}$. Ponadto został wybrany prezesem Koła Przyjaciół Związku Strzeleckiego ${ }^{58}$. Jako przewodniczący Przysposobienia Wojskowego i Wychowania Wojskowego organizował zajęcia i zawody sportowe ${ }^{59}$. Pełnił również funkcję przewodniczącego Komitetu Budowy Stadionu (1935), współuczestniczył w budowie kortów tenisowych oraz przyczynił się do powstania klubu sportowego „Unia”60.

Niekiedy organizowanie „państwowotwórczych” uroczystości wiązało się z licznymi trudnościami. Prześledźmy to na przykładzie prac Komitetu Obchodów Imienin Pierwszego Marszałka Polski Józefa Piłsudskiego w 1931 r. Już w lutym wystosował prezes BBWR Gurzyński pismo do podległych sobie urzędników, w którym zaznaczył, że uczczenie dziesięciolecia zwycięskie-

48 Tamże, k. 234; Jak uczciła Wielkopolska uchwalenie nowej konstytucji, „Nowy Kurier” 1935, nr 73, s. 7.

49 Swarzędz [Obchody 20-lecia niepodległości], „,Orędownik” 1938, nr 263, s. 5.

50 Jubileusz 25-letni Koła Śpiewackiego w Swarzędzu, "Nowy Kurier” 1929, nr 160, s. 12.

${ }^{51}$ Imponujący zlot okregowy Młodych Polek w Swarzędzu, „Nowy Kurier” 1933, nr 153, s. 10.

52 Wystawę ksiażki społecznej otwarto w Swarzędzu, "Orędownik” 1937, nr 270, s. 6.

${ }^{53}$ APP, Zespół 53/4389: Akta miasta Swarzędza, Jednostka 350: Obchody świąt narodowych, k. 185.

54 Tamże, k. 203.

${ }^{55}$ P. Okulewicz, Obóz sanacyjny w województwie poznańskim w latach 1926-1935 ..., s. 67.

${ }^{56}$ Do czytelników!!, „Zew Polski Zachodniej” 1934, nr 1, s. 1.

${ }^{57}$ APP, Ewidencja członków Związku Weteranów Powstań Narodowych Rzeczypospolitej Polskiej, Jednostka 53/884/0/1/44.

58 Z Koła Przyjaciót Związu Strzeleckiego, "Głos Swarzędza” 1934, nr 23, s. 3.

${ }^{59}$ [Ogłoszenie o zawodach sportowych], "Głos Swarzędza” 1934, nr 20, s. 6.

60 ,T. Kąkolewski, J. Kąkolewski, Unia Swarzędz 1921-2011, http://swarzedz.pbp.poznan. pl/files/unia1.pdf (dostęp: 13 kwietnia 2018 r.), s. 23. 
go odparcia najazdu Rosji bolszewickiej ma być połączone ze świętowaniem imienin Marszałka ${ }^{61}$. Po zebraniu w Poznaniu 25 lutego otrzymał Tadeusz Staniewski do rozpropagowania odezwę „Do Społeczeństwa Polskiego” ogólnopolskiego Komitetu Dziesięciolecia Zwycięskiego Odparcia Najazdu Rosji Sowieckiej zachęcającą obywateli do złożenia hołdu Budowniczemu Polski Odrodzonej poprzez nabywanie nalepek na okna sklepowe oraz pocztówek, które można wysłać na podany adres na Maderze ${ }^{62}$.

2 marca 1931 r. Tadeusz Staniewski wysłał zaproszenie do podległych sobie urzędników (wójt, kierownik szkoły, naczelnik poczty, sierżant), w celu utworzenia Komitetu Obchodów Imienin Pierwszego Marszałka Polski Józefa Piłsudskiego ${ }^{63}$. W piśmie z 3 marca wojewoda poznański zalecił burmistrzowi zaangażować się $\mathrm{w}$ obchody Imienin ${ }^{64} .5$ marca podobne ponaglenie przysłał starosta ${ }^{65}$. Następnie Tadeusz Staniewski rozsyłał zaproszenia do znaczących mieszkańców miasta, aby zechcieli do Komitetu wstąpić i wyrazić zgodę na umieszczenie swojego nazwiska pod odezwą Komitetu do Obywateli Swarzędza. Brak odpowiedzi miał oznaczać aprobatę, ale znaleźli się wśród swarzędzan tacy, którzy zadali sobie trud, by zaproszenie odesłać burmistrzowi z dopiskiem „odmawiam”66. Ostatecznie powstał bogaty program obchodów Imienin ${ }^{67}$, które w 1931 r. świętowano 18 i 19 marca. Obejmował on m.in.: capstrzyk, defiladę, akademię, występy orkiestry i chóru, deklamacje. Uroczystości nie miały spokojnego przebiegu, zakłóciła je manifestacja zorganizowana przez zwolenników Obozu Wielkiej Polski na cześć Romana Dmowskiego i Józefa Hallera. Rok później, także podczas obchodów Imienin Marszałka, członkowie OWP obrzucili osoby udające się na uroczystość surowymi jajkami. Doszło do bójki, podczas której członek OWP Czesław Jarczyński został pchnięty nożem. Obie te manifestacje znalazły swój finał w sądzie ${ }^{68}$.

Jako burmistrz Tadeusz Staniewski odnosił się z szacunkiem do przedstawicieli ugrupowań opozycyjnych. Potwierdza to jego odpowiedź na pismo starosty powiatowego z 15 listopada 1933 r., w którym starosta domagał się, by burmistrz wysłał mu swe przewidywania co do wyniku wyborów i scharakteryzował kandydatów. Co do listy nr 1 - Narodowego Bloku Gospodarczego, na której znajdowali się członkowie i sympatycy BBWR, Tadeusz Staniewski

${ }^{61}$ APP, Zespół 53/4389: Akta miasta Swarzędza, Jednostka 350: Obchody świąt narodowych, k. 29.

${ }^{62}$ Tamże, k. 31.

63 Tamże, k. 32.

${ }^{64}$ Tamże, k. 33.

65 Tamże, k. 36.

66 Tamże, k. 41-55.

67 Tamże, k. 72.

${ }^{68}$ Z. Kaczmarek, W Polsce odrodzonej..., s. 188. 
pisał: „jest ogólne zdanie w mieście, że najpoważniejszych kandydatów ma lista nr 1". Kandydaci z tej listy są popularni „ze względu na hojną rękę przy każdej akcji charytatywnej". Lista nr 2 - to Niemcy, popularni w swoich kręgach. Natomiast o liście nr 3 - liście opozycyjnego Obozu Narodowego pisał: „zawiera wybitnych działaczy Stronnictwa Narodowego". Przewidywany przez niego wynik wyborów to: BBWR - pięciu radnych, Niemcy - jeden, Stronnictwo Narodowe - sześciu ${ }^{69}$.

Przewidywania Tadeusza Staniewskiego co do wyniku wyborów okazały się słuszne. Jednak mimo że endecja zdobyła - i zachowała - przewagę w Radzie Miasta, Tadeusz Staniewski utrzymał się na stanowisku burmistrza.

Skuteczne działanie mogła ułatwić mu reforma samorządu terytorialnego z marca 1933 r. „Ograniczyła ona zakres działania Rady Miejskiej na korzyść Zarządu Miejskiego, wprowadzonego w miejsce dotychczas istniejącego Magistratu. W zarządzie Miejskim funkcjonowało kolegium powołane do podejmowania decyzji $\mathrm{w}$ sprawach realizacji budżetu, ustanowienia opłat za korzystanie z urządzeń zakładów miejskich, opiniowanie i uchwalanie regulaminów oraz instrukcji dla urzędów i zakładów miejskich. W skład Magistratu, a później Zarządu Miejskiego wchodził burmistrz, wiceburmistrz i ławnicy. Poza sprawami zastrzeżonymi dla kolegium Zarządu Miejskiego burmistrz działał jednoosobowo, gdyż był przełożonym i kierownikiem całej administracji oraz gospodarki miasta" ${ }^{70}$.

Ustawa ta umożliwiła także znaczne powiększenie powierzchni miasta poprzez włączenie w jego obszar sąsiednich gmin: Swarzędz-Wieś i Swarzędz-Dwór, które były ściśle związane z miastem życiem społeczno-gospodarczym, ale do czerwca 1934 r. stanowiły osobne jednostki administracyjne. W wyniku tych zmian powierzchnia Swarzędza powiększyła się ze 131 hektarów do 572, a liczba ludności wzrosła do 4900 osób. Arkadiusz Małyszka ocenia, że „zmiana granic miasta Swarzędza z połowy lat trzydziestych XX w., kiedy burmistrzem był Tadeusz Staniewski, zdecydowała, w dużej mierze, o jego dzisiejszym kształcie. Miasto zyskało tereny, na których w drugiej połowie XX w. powstało całe drugie miasto - osiedla północne Swarzędzkiej Spółdzielni Mieszkaniowej"71.

Wraz ze wzrostem terytorialnym następował rozwój infrastruktury komunalnej miasta. Zdaniem Zygmunta Kaczmarka, „władze miejskie prowadziły racjonalną gospodarkę finansową, choć trzeba stwierdzić, że nie stroni-

${ }^{69}$ APP, Zespół 53/4389: Akta miasta Swarzędza, Jednostka 295: Wybory do Rady Miejskiej, k. 18 - Pismo starosty; k. 19 - Odpowiedź burmistrza.

${ }^{70}$ W. Białek, Swarzędz 1638-1988..., s. 94-95.

${ }^{71}$ A. Małyszka, Zmiana granic Swarzędza w czasach sprawowania urzędu burmistrza przez Tadeusza Staniewskiego (1934 rok), [w:] Tadeusz Staniewski 1873-1940..., s. 25-33. 
ły od zaciągania kredytów, które wykorzystały na cele inwestycyjne. Ponadto trzeba stwierdzić, że władze niemieckie pozostawiły znaczny dług zaciągnięty na pobudowanie gazowni, rzeźni i wodociągów, który trzeba było spłacać"72. Dzięki istnieniu rzeźni miejskiej miasto było samowystarczalne w zakresie zaopatrzenia w mięso i jego przetwory. Moce przerobowe rzeźni nie były do końca wykorzystane, dlatego zdarzało się, że przynosiła ona miastu straty. Niemniej w latach 1937-1938 zainwestowano w remont rzeźni. Natomiast znaczne dochody przynosiła gazownia, którą także stopniowo unowocześniano w latach 1934-1938. Zyskowne były także wodociągi miejskie, których sieć rozbudowano w 1934 r. i wyremontowano w latach 19381939. Najpoważniejsze inwestycje wiązały się z elektryfikacją miasta. 10 października 1935 r. Rada Miejska uchwaliła „powołanie miejskiego zakładu elektrycznego i postanowienie w sprawie koncesji i pożyczki"73. W Aktach miasta Swarzędza znajduje się, podpisany przez Tadeusza Staniewskiego, „Plan sfinansowania zakładu elektrycznego w Swarzędzu”74 z 24 lutego 1936 r. Wynika z niego, że majątek gminy Swarzędz wynosił wówczas 1021202,39 zł przy jednoczesnym zadłużeniu 83433,43 zł (pożyczki długoterminowe na miejskich zakładach użyteczności publicznej). Koszty budowy zakładu elektrycznego oszacowano na 40000 zł i planowano je pokryć z pożyczki zaciągniętej w wysokości 20000 zł w Komunalnym Banku Kredytowym w Poznaniu oraz z pożyczki ofiarowanej miastu przez mieszkańców. W tym planie Tadeusz Staniewski uznał, że „rentowność projektowanego zakładu elektrycznego jest zapewniona, gdyż w mieście znajduje się 128 samodzielnych przedsiębiorstw stolarskich, które niecierpliwie czekają na energię elektryczną". 18 listopada 1937 r. do Zarządu Miasta w Swarzędzu wpłynęło zawiadomienie, że „Elektrownia Miejska w Poznaniu rozpoczyna z dniem dzisiejszym zaciąganie przewodów dla linii wysokiego napięcia PoznańSwarzędz i odcinki budowanej linii włączone będą pod napięcie próbne na godziny wieczorne i nocne" 75 .

Tadeusz Staniewski dbał nie tylko o rozwój zakładów podległych Zarządowi Miasta, ale i o poprawę standardu życia swarzędzan. Stopniowo coraz większa liczba mieszkań korzystała z dostępu do gazu i kanalizacji, wyłożono Rynek nową brukową nawierzchnią i rozpoczęto brukowanie ulic ${ }^{76}$. Jeden z mieszkańców miasta Stefan Dytkiewicz tak napisał o Swarzędzu

72 Z. Kaczmarek, W Polsce odrodzonej..., s. 137.

${ }^{73}$ APP, Zespół 53/4389: Akta miasta Swarzędza, Jednostka 311: Uprawnienia rządowe i plany, k. 11.

${ }^{74}$ Tamże, k. 25.

75 APP, Zespół 53/4389: Akta miasta Swarzędza, Jednostka 310: Miejski Zakład Elektryczny w Swarzędz, k. 37.

76 Tadeusz Staniewski był konsekwentny w dbałości o czystość miasta, wdał się nawet w proces z własnym synem Witoldem po tym, jak w $1934 \mathrm{r}$. wezwał go pismem do usunięcia 
w 1936 r.: „Ojcowie miasta Swarzędza sprawili, że wyróżnia się ono postępem i ładem od pozostałych miast Wielkopolski z liczbą ponad 5 tys. mieszkańców. W minionym dziesięcioleciu rozbudowano miasto wszerz i wzdłuż, uzdrawiano i uestetyzowano najmniejsze zaułki, ozdobiono peryferie zielenią i drzewami"77.

Szczególnie należy podkreślić działalność Tadeusza Staniewskiego na rzecz najuboższych i najbardziej potrzebujących mieszkańców, zwłaszcza w okresie kryzysu gospodarczego z lat 1929-1933. Wielki kryzys dotarł do Swarzędza z pewnym opóźnieniem, gdyż wielu stolarzy swarzędzkich znalazło zatrudnienie przy Powszechnej Wystawie Krajowej w Poznaniu. Sytuacja załamała się w drugiej połowie 1931 r., kiedy zamknięto największy zakład produkcyjny w mieście, fabrykę mebli Antoniego Tabaki. Dokumenty, jakie zachowały się w Aktach miasta Swarzędza, potwierdzają, jak energicznie działał Tadeusz Staniewski na rzecz najuboższych i jak wytrwale mobilizował do podobnej aktywności swych obywateli. Już 7 października $1931 \mathrm{r}$. wystosował do wszystkich liczących się obywateli w mieście następujące "Zaproszenie": „Celem utworzenia Komitetu Pomocy bezrobotnym na miasto Swarzędz zapraszam uprzejmie niżej podanych Panie i Panów do przybycia na posiedzenie, które się odbędzie w piątek dnia 9 b.m. o godz. 6 wieczorem na sali posiedzeń $\mathrm{w}$ ratuszu. Spodziewam się, że nikogo z zaproszonych nie zabraknie, aby dopomódz [!] ciężkiej doli bezrobotnym, obmyślić sposoby dania zatrudnienia lub niesienia pomocy bezrobotnym w nadchodzącej zimie" $^{\prime \prime 8}$.

Na tym zebraniu najwidoczniej Komitet ukonstytuował się, gdyż już 12 października Tadeusz Staniewski rozsyłał kolejne "Zaproszenie": „Posiedzenie Komitetu Pomocy Bezrobotnym na miasto Swarzędz odbędzie w środę dnia 14 b.m. o godz. 6 wieczorem na sali posiedzeń w ratuszu. Na porządku obrad: podział pracy komitetu i wybór poszczególnych komisji. Ze względu na ważność sprawy proszę o łaskawe bezwzględne przybycie wszystkich zaproszonych"79. Natomiast 20 października opublikował następujące "Ogłoszenie": „Wzywam wszystkich bezrobotnych nie pobierających zasiłku do osobistego zgłoszenia się w biurze Magistratu od poniedziałku $26 \mathrm{bm}$. począwszy do środy $28.10 .31 \mathrm{w}$ godzinach $8-10$ przed południem celem rejestracji" ${ }^{\prime \prime}$.

nieczystości z posesji i zbudowania osobnego dołu z nakryciem do zlewania pomyj. Zob. APP, Zespół 53/4389: Akta miasta Swarzędza, Jednostka 319: Drogi i place, k. 92.

77 S. Dytkiewicz, Swarzędz miasto stolarzy..., s. 3.

${ }^{78}$ APP, Zespół 53/4389: Akta miasta Swarzędza, Jednostka 341: Pomoc dla bezrobotnych, k. 2.

\footnotetext{
79 Tamże, k. 4.

${ }^{80}$ Tamże, k. 8.
} 
Kolejne zebranie Komitetu odbyło się 19 października ${ }^{81}$. Rozsyłano listy do wszystkich towarzystw i organizacji działających na terenie miasta z prośbą o finansowe wsparcie działalności komitetu ${ }^{82} .22$ października $1931 \mathrm{r}$. Tadeusz Staniewski ogłosił „Odezwę do wszystkich pp. urzędników i pracowników miejskich": „Za przykładem wszystkich urzędów obowiązkiem jest również naszym zdeklarować pewną kwotę na rzecz pomocy bezrobotnym. Ogólnie przyjęty jest jeden procent od miesięcznych poborów. Jestem pewien, że pp. pracownicy i urzędnicy miejscy mają dostateczne społeczne zrozumienie akcji pomocy bezrobotnym i od tego zaszczytnego obowiązku ofiary dla cierpiących biedy i nędzy się nie uchylą. Celem jednolitego wykonania zarządziłem, by p. rachmistrz Kędzia przy wypłacie poborów od 1.11.31 do 1.4. 31 [?] bezpośrednio potrącał odnośne kwoty w wysokości 1\%. Proszę swoim podpisem potwierdzić przystąpienie do powyższej propozycji”"83.

Na dwanaście nazwisk widocznych poniżej przy czterech widnieje dopisek „nie podpisuje".

Kolejne posiedzenia Komitetu odbywały się właściwie co tydzień - 6 listopada, 14 listopada, 3 grudnia... Na zebraniach omawiano wyniki kwesty. Komitet gromadził nie tylko gotówkę, ale także węgiel i artykuły spożywcze, które rozdzielano między potrzebujących. Według pism słanych przez Tadeusza Staniewskiego do Wydziału Powiatowego, w Swarzędzu 28 października 1931 r. bezrobotnych było 75 (w tym ośmiu korzystających z zapomogi Państwowego Funduszu Bezrobotnych), według stanu z 14 listopada 102 osoby (w tym 78 robotników niewykwalifikowanych) ${ }^{84}$.

Na rzecz bezrobotnych zorganizowano także zabawę sylwestrową, która przyniosła $172,50 \mathrm{zł}^{85}$. Tadeusz Staniewski wspierał komitet również z własnych funduszy. Potwierdza to następujące "Podziękowanie”, podpisane przez skarbnika Antoniego Zieglera: „Z okazji ślubu córki swej Haliny z p. Ryszardem Millerem, który się odbędzie w wtorek dnia 29.12.1931 o godz. 5 po poł. $\mathrm{w}$ kościele parafialnym ofiarował $\mathrm{w}$ miejsce uwiadomień p. burmistrz Tadeusz Staniewski na rzecz bezrobotnych 50 zł., za co imieniem Komitetu składam szczere podziękowanie" 86 .

Niestety, środki pochodzące z kwesty były niewystarczające i szybko się wyczerpywały. Świadczy o tym „Prośba bezrobotnych do Magistratu i Rady Miejskiej" z 19 lutego 1932 r.: "Jesteśmy od kilku miesięcy bez pracy i bez środków utrzymania. Zapomogi z funduszu bezrobocia nie pobieramy, należymy do tej kategorji pracowników, którzy pracowali pojedynczo, przez co

\footnotetext{
${ }^{81}$ Tamże, k. 10.

82 Tamże, k. 15.

${ }^{83}$ Tamże, k. 16.

${ }^{84}$ Tamże, k. 36, 42.

85 Tamże, k. 87, 92.

${ }^{86}$ Tamże, k. 86.
} 
nie mamy prawa do zapomogi. Tutejszy Komitet niesienia Pomocy bezrobotnym wyczerpał swoje fundusze, tak że my bezrobotni nie mamy dalszej drogi do życia" 87 .

Jedynym skutecznym działaniem było podjęcie przez miasto prac, przy których bezrobotni znaleźliby zatrudnienie. Już wiosną $1931 \mathrm{r}$. Wydział Powiatowy udzielił swarzędzkiemu magistratowi subwencji w wysokości 1500 zł, przez co umożliwił rozpoczęcie prac przy naprawie bruków miejskich $^{88}$. Niestety, środki te szybko się skończyły, a prośba o kolejne dwa, trzy tysiące zapomogi przyniosła reprymendę Starosty: „Dalsza zapomoga nie może być udzielona. Zarazem polecam ściągnąć zaległe podatki od pp. Staniewskiego, Zębskiego, Gruszczyńskiego itp. A wówczas będzie Magistrat mógł zatrudnić tutejszych bezrobotnych z własnych funduszów".

W latach 1934-1935 ukazywało się w Swarzędzu lokalne czasopismo pod tytułem „Głos Swarzędza”. Na jego łamach stale pamiętano o problemie bezrobotnych i nawoływano: „Oni nie chcą zapomogi, ani jałmużny, chcą pracy”. 22 listopada zaproszono mieszkańców na ogólne zebranie, celem powołania Lokalnego Komitetu Funduszu Pracy ${ }^{89}$. Pomysł ten został przychylnie przyjęty przez swarzędzan. Kolejna odezwa głosiła, że: „Dnia 23 listopada z inicjatywy burmistrza zawiązał się komitet, aby zatrudnić ludzi bez pracy przy zakładaniu kanalizacji miasta i niwelacji terenów, i pracę tę wynagradzać $\mathrm{z}$ datków, o które apelujemy do was, Obywatele ${ }^{\prime \prime 9}$. W ciągu jednego miesiąca swarzędzanie zadeklarowali się na kwotę 2118,35 zł. Komitet Funduszu Pracy pod przewodnictwem Tadeusza Staniewskiego uchwalił podjęcie następujących prac: kanalizacja, planowanie placu pod boisko sportowe i niwelowanie ulic ${ }^{91}$. W grudniu "Głos Swarzędza” mógł donieść: „Projekty realizują się!" - pierwsze prace ziemne rozpoczęto 19 grudnia, zatrudniając 25 robotników $^{92}$.

Niemniej, mimo pewnych sukcesów, problemu bezrobocia nie udało się do końca rozwiązać, jeszcze w lipcu 1939 r. zasiłki w Swarzędzu pobierały 274 osoby $^{93}$. W 1937 r. „za zasługi na polu opieki społecznej” miano odznaczyć Tadeusza Staniewskiego Złotym Krzyżem Zasługi. Do tej uroczystości jednak nie doszło. Jak czytamy w notatce podpisanej przez wojewodę poznańskiego Artura Maruszewskiego, 17 kwietnia doszło w Swarzędzu do rozruchów. Burmistrz zarządził, że bezrobotni mają otrzymać wypłatę za wypracowane przez siebie dniówki w poniedziałek 19, a nie w sobotę 17 kwietnia.

\footnotetext{
${ }^{87}$ Tamże, k. 133.

88 Tamże, k. 157.

${ }^{89}$ Odezwa do Obywateli, "Głos Swarzędza” 1934, nr 23, s. 1.

${ }^{90}$ [Odezwa Komitetu Funduszu Pracy], "Głos Swarzędza” 1934, nr 25, s. 1.

${ }^{91}$ Z działalności Lokalnego Komitetu Funduszu Pracy, "Głos Swarzędza” 1934, nr 29, s. 2.

${ }^{92}$ Projekty realizują się!, „Głos Swarzędza” 1934, nr 30, s. 1.

${ }^{93}$ Z. Kaczmarek, W Polsce odrodzonej..., s. 126.
} 
Policja spowodowała, że sekretarz magistratu dokonał wypłaty. „Ze względu na podniecenie w Swarzędzu odznaczenie burmistrza w chwili obecnej mogłoby wywołać zły oddźwięk" ${ }^{\prime 94}$.

Tadeusz Staniewski troszczył się o umocnienie pozycji rzemiosła, uczestniczył w wydarzeniach ważnych dla cechu stolarzy, takich jak: otwarcie Targów Meblowych, utworzenie spółdzielni „Jedność” czy budowa pawilonu wystawienniczego przy ulicy Wrzesińskiej, do dziś jednego z najbardziej rozpoznawalnych budynków miasta ${ }^{95}$. Rozkwit swarzędzkiego meblarstwa $\mathrm{w}$ drugiej połowie lat 30 . znacznie przyczynił się do rozwoju miasta. Temu pomyślnemu procesowi położyło kres wkroczenie wojsk niemieckich we wrześniu 1939 r. Aresztowanie Tadeusza Staniewskiego zakończyło pełnienie przez niego funkcji burmistrza.

\section{Zakończenie}

W 1936 r. mieszkaniec Swarzędza Stefan Dytkiewicz tak pisał o swoim mieście: „Mimo zaniku konsumpcji, nadmiernych obciążeń świadczeniami państwowemi i socjalnemi, wreszcie nieuczciwej konkurencji niefachowców, Swarzędz przykładnie kroczy naprzód. Bo zmora kryzysu dotknęła również ciężko Swarzędz. Toteż 〈kolebka meblarstwa〉 stoi w obliczu wielu podstawowych trosk, zmagań i kłopotów. Swarzędz ma jednak ambicję i na szarym końcu pozostać nie myśli. $W$ dalszym ciągu rośnie i rozbudowuje się. Miastu potrzeba pomocy i poparcia w zamierzeniach rzutkiego gospodarza p. Staniewskiego, który ze swoimi współpracownikami skutecznie pracuje i tworzy" ${ }^{\prime \prime 6}$.

Zawarte w powyższym cytacie określenie Tadeusza Staniewskiego: „rzutki gospodarz" wydaje się najlepszym opisem jego osoby, a charakterystyczna dla niego energia i sumienność w pełnieniu obowiązków sprzyjały rozwojowi miasta. W ciągu wielu lat jego działalności doczekał się kilku krytycznych osądów ze strony współobywateli czy zwierzchników, jednak tego rodzaju polemiki są rzeczą zwykłą w świecie politycznej rywalizacji. Wydaje się, że można zgodzić się z opiniami badaczy historii Swarzędza ${ }^{97}$, iż w okresie, kiedy Tadeusz Staniewski był burmistrzem, miasto zaczęło powoli rozkwitać.

${ }^{94}$ APP, Zespół 53/296: Urząd Wojewódzki Poznański, Jednostka 167: Wnioski o odznaczenia, k. 80.

${ }^{95}$ Otwarcie spótdzielni stolarskiej "Jedność" w Swarzędzu, "Orędownik” 1937, nr 185, s. 6; Otwarcie Targów Meblowych, "Nowy Kurier” 1938, nr 203, s. 9; Otwarcie Targów w Swarzędzu, „Orędownik" 1938, nr 204, s. 2; Otwarcie Targów w Swarzędzu. Strajk w Swarzędzu trwa, "Gazeta Polska" 1938, nr 204, s. 1.

${ }^{96}$ S. Dytkiewicz, Swarzedz miasto stolarzy..., s. 21.

${ }^{97}$ Z. Kaczmarek, W Polsce odrodzonej..., s. 132; W. Białek, Swarzędz 1638-1988 .., s. 98. 
Utrwalona została reputacja Swarzędza jako „stolicy polskiego meblarstwa”, która wyznaczyła kierunek rozwoju miasta także po II wojnie światowej.

Współcześnie w Swarzędzu Tadeusz Staniewski pamiętany jest przede wszystkim jako „człowiek wielkiego serca, którego wyróżnia wrażliwość na cudzą krzywdę. Umie pomóc potrzebującym, organizuje w Swarzędzu jadłodajnię dla bezrobotnych, wspiera razem z żoną Haliną funkcjonowanie ochronki dla dzieci z biednych rodzin, często przekazuje ofiary na cele społeczne. Tadeusz Staniewski szanował ludzi i był przez nich szanowany, o czym świadczy zdarzenie opowiedziane przez jego wnuczkę Justynę Staniewską. Po wybuchu II wojny światowej został aresztowany przez Niemców za działalność patriotyczną i był przetrzymywany w Forcie VII w Poznaniu. Wtedy został rozpoznany przez współwięźnia, mieszkańca Swarzędza, który roznosił ludziom porcje chleba. Ten człowiek oddał Staniewskiemu swoją kromkę chleba, gdy rozpoznał w nim byłego burmistrza. Była to symboliczna forma podziękowania za wszystkie dobra, jakimi przysłużył się były burmistrz Swarzędza mieszkańcom miasta" ${ }^{\prime 2}$.

Szczepan Pokornowski we wspomnieniach Z działalności socjalistycznej w Swarzędzu (1930-1937) opisuje epizod ukazujący autorytet, jakim cieszył się Tadeusz Staniewski wśród społeczności swarzędzkiej. W 1935 r. Pokornowski próbował założyć związek zawodowy wśród robotników huty szkła w Antoninku. Zebranie organizacyjne odbyło się w sali Bractwa Kurkowego w Swarzędzu, a przybyli na nie także czeladnicy stolarscy i burmistrz. Nim przewodniczący zebrania przestawił cele i zadania związku, zagłuszyli go zwolennicy Stronnictwa Narodowego obraźliwymi okrzykami. Wobec powstałego zamieszania burmistrz rozwiązał zebranie. „Wyszedłszy z Sali w kilku kroczyliśmy o kilkanaście kroków za wracającymi na rynek burmistrzem i policjantami. Robiliśmy to celowo, bowiem za nami postępowała bojówka Jarczyńskiego, zaś w krzakach rosnących na skarpie przydrożnej widzieliśmy kilkuosobowe grupki zwolenników i najemników Stronnictwa Narodowego, unikających szermierki myślowej i argumentacyjnej, lecz lubujących się w kasteciarstwie i nożowniczych rękoczynach. Zamierzali oni dokonać napadu na nas, ale wobec ogólnie w mieście poważanego burmistrza i funkcjonariusza policji zrobić tego nie śmieli"99.

Tadeusz Staniewski może być uznany za przykład wybitnego samorządowca lokalnego szczebla. Jako droga życiowa pokazuje, z jakimi trudnościami zmagali się Polacy, budując zręby społeczeństwa obywatelskiego. Najpierw, w czasach zaborów, organizowanie kasy oszczędnościowej pod

98 Tadeusz Staniewski 1873-1940..., s. 8.

${ }^{99}$ S. Pokornowski , Z działalności socjalistycznej w Swarzędzu (1930-1937), [w:] Kartki robotniczych wspomnień: z życia i walki w Wielkopolsce w latach 1918-1945, wybór i oprac. A. Czubiński i M. Olszewski, Poznań 1972, s. 334. 
auspicjami księdza Piotra Wawrzyniaka, potem przygotowywanie powstania, działalność radnego, w końcu zarządzanie miastem po przewrocie majowym. W ogniu partyjnych i partykularnych sporów Tadeusz Staniewski rozwijał swoje zdolności organizacyjne i budował struktury demokratyczne, często bez wsparcia państwa

\section{Bbliografia}

\section{Źródła archiwalne}

Archiwum Państwowe w Poznaniu

Akta miasta Swarzędz, Zespół 53/4389, Jednostki serii 2.1 -2.5: Okres 20-lecia międzywojennego.

Urząd Wojewódzki Poznański, Zespół 53/296, Jednostki: 1481 Administracja miasta Swarzędza; 167 Wnioski o odznaczenia.

Związek Powstańców Wielkopolskich w Poznaniu, Zespół: 53/884, Jednostka 44 Ewidencja członków Związku Weteranów Powstań Narodowych Rzeczypospolitej Polskiej.

\section{Artykuły prasowe}

Czeladź stolarska postanowiła walczyć aż do zwycięstwa, „Nowy Kurier” 1938, nr 203.

Do czytelników!, ",Zew Polski Zachodniej” 1934, nr 1.

II-gie Targi meblowe w Swarzędzu, „Nowy Kurier” 1935, nr 161.

Imponujacy zlot okręgowy Młodych Polek w Swarzędzu, „Nowy Kurier” 1933, nr 153.

Jak uczcita Wielkopolska uchwalenie nowej konstytucji, „Nowy Kurier” 1935, nr 73.

Jubileusz 25-letni Koła Śpiewackiego w Swarzędzu, „Nowy Kurier” 1929, nr 160, s. 12.

O umowę zbiorowa w przemyśle stolarskim w Swarzędzu, „Nowy Kurier” 1938, nr 143.

Obwieszczenie Rady Ludowej w Swarzędzu, "Orędownik Powiatu Poznańskiego-Wschodniego" $1919, \mathrm{nr} 7$.

Odezwa do Obywateli, „Głos Swarzędza” 1934, nr 23.

[Odezwa Komitetu Funduszu Pracy], „Głos Swarzędza” 1934, nr 25.

[Ogłoszenie o zawodach sportowych], "Głos Swarzędza” 1934, nr 20.

Otwarcie spótdzielni stolarskiej „Jedność" w Swarzędzu, „Orędownik” 1937, nr 185.

Otwarcie Targów Meblowych, „Nowy Kurier” 1938, nr 203.

Otwarcie Targów w Swarzędzu, „Orędownik” 1938, nr 204.

Otwarcie Targów w Swarzędzu. Strajk w Swarzędzu trwa, "Gazeta Polska” 1938, nr 204.

P. Komisarz rządowy w roli kacyka. Głos obywateli m. Swarzędza, „Dziennik Poznański” 1926, nr 222.

Pierwsze dni powstania 1918 r., "Głos Swarzędza” 1934, nr 32; 1935, nr 1; 1935, nr 2; nr 4.

Projekty realizują się!, „Głos Swarzędza” 1934, nr 30.

Przed zamknięciem Targów Meblowych, „Orędownik” 1938, nr 218.

(sd), Swarzędz. Izba rzemieślnicza wystawcom meblowym, „Kurier Poznański” 1935, nr 7.

Strajk stolarzy w Swarzędzu, "Orędownik” 1937, nr 93; nr 94; nr 95.

Swarzędz - miasto stolarzy. Drogi rozwoju, potrzeby i bolaczki pracowitego sasiada stolicy Wielkopolski, „Nowy Kurier" 1931, nr 267.

Swarzędz [Obchody 20-lecia niepodległości], „Orędownik” 1938, nr 263.

Swarzędz [Obchody rocznicy 3 Maja], „Goniec Wielkopolski” 1922, nr 104.

Swarzędz pod znakiem IV Targów Meblowych, „Orędownik” 1938, nr 202.

Szyna, Wszystkie pitki, dłuta, heble Robia meble, meble, meble... Miasto stolarzy - Targi Meblowe w Swarzędzu, „Ilustracja Polska” 1934, nr 41. 
[Utworzenie Rady Żołnierzy i Robotników w Swarzędzu], „Postęp” 1918, nr 267.

W przededniu IV. Targów Meblowych w Swarzędzu, „Nowy Kurier” 1938, nr 191.

W sprawie Targów Meblowych w Swarzędzu, "Orędownik” 1938, nr 263.

Wielkie zebranie stolarzy w Swarzędzu domaga się zawieszenia zarządu Targów Meblowych, „Kurier Poznański" 1938, nr 498 [wyd. wieczorne].

Wystawę książki społecznej otwarto w Swarzędzu, „Orędownik” 1937, nr 270.

Z działalności Lokalnego Komitetu Funduszu Pracy, "Głos Swarzędza” 1934, nr 29.

Z Koła Przyjaciół Związku Strzeleckiego, „Głos Swarzędza” 1934, nr 23.

\section{Opracowania}

Białek W., Swarzędz 1638-1988, Swarzędz 1988.

Buczyński W., Tadeusz Staniewski jako organizator i działacz społeczny, na przykładzie ochrony przeciwpożarowej Swarzędza, [w:] Tadeusz Staniewski 1873-1940, pod red. I. Sobczyk, Swarzędz 2010.

Czubiński A., Wielkopolska w latach 1918-1939, Poznań 2000.

Demel Cz., Krawulski J., Rzepa K., Działalność NSR i NPR w Wielkopolsce w latach 1917-1937, Warszawa-Poznań 1980.

Dytkiewicz S., Swarzędz miasto stolarzy, Swarzędz 1936.

Dzieje Swarzędza: monografia (1638-1988), pod red. S. Nawrockiego, Poznań 1988.

Fiedler F., Powstanie Wielkopolskie: mieszkańcy Swarzędza w zwycięskim zrywie niepodległościowym 1918-1919, Swarzędz 2007.

Kaczmarek Z. W Polsce odrodzonej, [w:] Dzieje Swarzędza: monografia (1638-1988), pod red. S. Nawrockiego, Poznań 1988.

Kąkolewski T., Kąkolewski J., Unia Swarzędz 1921-2011, http:/ / swarzedz.pbp.poznan.pl/files/ unia1.pdf (dostęp: 6 lutego 2020 r.)

Ksit B., Działalność publiczna Tadeusza Staniewskiego w Swarzędzu do roku 1918, „Przegląd Archiwalno-Historyczny" 2018, t. 5.

Małyszka A., Zmiana granic Swarzędza w czasach sprawowania urzędu burmistrza przez Tadeusza Staniewskiego (1934 rok), [w:] Tadeusz Staniewski 1873-1940, pod red. I. Sobczyk, Swarzędz 2010.

Nawrocki S., Pod zaborem pruskim, [w:] Dzieje Swarzędza: monografia, pod. red. S. Nawrockiego, Poznań 1988.

Okulewicz P., Obóz sanacyjny w województwie poznańskim w latach 1926-1935, Poznań 2014.

Pokornowski Sz., Z działalności socjalistycznej w Swarzędzu (1930-1937), [w:] Kartki robotniczych wspomnień: z życia i walki w Wielkopolsce w latach 1918-1945, wybór i oprac. A. Czubiński i M. Olszewski, Poznań 1972.

Stownik jezzyka polskiego, pod red. J. Karłowicza, t. 1, Warszawa 1900.

Szafran A.M., Tadeusz Staniewski (1873-1940), delegat Swarzędza na Polski Sejm Dzielnicowy, „Przegląd Wielkopolski” 2007, nr 2.

Szałek M., Tadeusz Staniewski: pierwszy burmistrz Swarzędza w odrodzonej Polsce, „Prosto z Ratusza” 2007, nr 10.

Tadeusz Staniewski 1873-1940, pod red. I. Sobczyk, Swarzędz 2010.

Udziat mieszkańców Swarzędza i okolic w Powstaniu Wielkopolskim 1918-1919, pod red. A. Bartoszek, A. Małyszka, M. Pokorskiego, Poznań 2015. 


\title{
Działalność publiczna Tadeusza Staniewskiego w Swarzędzu w latach 1918-1939
}

\begin{abstract}
Streszczenie
Niniejszy artykuł ma być próbą poszerzenia wiadomości na temat Tadeusza Staniewskiego (1873-1940) na podstawie zbiorów Archiwum Państwowego w Poznaniu i wielkopolskiej prasy. W 1919 r. objął stanowisko burmistrza w podpoznańskim mieście Swarzędz. Piastował je przez 9 miesięcy. Ponownie wybrany burmistrzem w 1929 r., pełnił tę funkcję do 1939 r. Ta dekada to okres powolnego rozkwitu miasta. Swarzędz zyskał reputację „stolicy polskiego meblarstwa". W swoim mieście Tadeusz Staniewski cieszył się uznaniem jako kupiec i człowiek oddany działalności obywatelskiej. Zwolennik Narodowej Partii Robotniczej, po zamachu majowym przyłączył się do secesyjnej grupy NPR-Lewica, popierającej Józefa Piłsudskiego. Następnie stał się członkiem Bezpartyjnego Bloku Współpracy z Rządem. Później wspierał działalność Obozu Zjednoczenia Narodowego. Z szacunkiem odnosił się do przedstawicieli ugrupowań opozycyjnych. Mimo że w Radzie Miasta Swarzędza zdobyli przewagę zwolennicy endecji, Tadeusz Staniewski utrzymał się na stanowisku burmistrza. Na szczególną uwagę zasługuje jego działalność charytatywna i zaangażowanie na rzecz zwalczania bezrobocia na terenie miasta.
\end{abstract}

Słowa kluczowe: Staniewski Tadeusz, Swarzędz

Barbara Ksit

\section{Public activity of Tadeusz Staniewski in Swarzędz in the years 1918-1939}

\begin{abstract}
The article presents the activity of Tadeusz Staniewski (1873-1940), a merchant and social activist, in the town of Swarzędz, near Poznań, in the years 1918-1939. The following sources were used for the purpose of writing this article: the collection of the State Archive in Poznan, as well as articles in Greater Poland press, mainly in periodicals. In 1919, Staniewski became the mayor of Swarzędz and held this position for nine months. In 1929, he was yet again elected mayor, but this time held this position for a decade. For the town, this was a time of a gradual rise to prosperity. Swarzędz became known as the "furniture capital of Poland". In his town, Tadeusz Staniewski was a respected merchant and a dedicated civil servant. He was a supporter of the National Workers' Party, and after the May coup, he joined one of its factions the Left, which supported Józef Piłsudski. Later, he became a member the Nonpartisan Bloc for Cooperation with the Government. In subsequent years, he supported the activities of the Camp of National Unity. His attitude towards the representatives of the opposition remained respectful. Even though the representatives of the National Democracy gained majority in the Swarzędz City Council, Tadeusz Staniewski kept his position as mayor. His charitable activity and commitment towards combating unemployment in his town are particularly noteworthy.
\end{abstract}

Keywords: Staniewski Tadeusz, Swarzędz 